\title{
暖地向け酒米新品種「ちほのまい」の 育成とその特性
}

焼酎の生産, 消費が盛んな宮崎県でも, 古くから日本酒と酒米の生産が続けられている。宮崎県が新しく 育成した酒米品種「ちほのまい」は栽培しやすく, 収量も多い。心白がやや大きく, 高度精白にはやや不向 きであるが, 酒質はまろやかでコクがあり, 今後の利用が期待されている。本稿では酒米新品種「ちほのま い」の特性を紹介していただいた。

\section{松 浦 聡 司}

\section{はじめに}

宮崎県で生産される酒類の大半はさつま芋等を主原 料とした焼酎であり, 本県は焼酎の一大産地として全 国的にも知られる存在である。

このため焼酎は広く飲まれている一方で, 日本酒の 本県に打ける成人一人当たりの消費量は酒類消費量全 体の $3 \%$ 程度と少なく, 比較的なじみがうすい酒類で ある。

しかしながら，本県でも 2 社が日本酒を生産してお り, うち A 社は県内唯一の日本酒専門蔵として県北 部の延岡市で操業している。延岡市を中心とした県北 部地域では古くから日本酒を飲む習慣があり県内でも 比較的日本酒の需要が多い地域で, この蔵では県北部 中山間地域との契約栽培で生産された酒米を利用した 酒造りを行っている。

主要産地である県北部の中山間地域では酒米は契約 栽培で安定した収入の見込める品目であることから水 田農業の重要な品目の一つとなっており, 15 ha 程度 が作付されている。

品種としては現在 $\mathrm{A}$ 社の主力商品の原料として「は なかぐら」や大吟醸等の高級酒の原料として「山田 錦」が栽培されている。「はなかぐら」は 2000 年に酒 米の生産拡大のため本県初の酒米として育成された品 種で,「山田錦」より短稈で作りやすく多収である。し かし, 近年は心白発現率が低く, 品質低下とそれに伴
う販売価格の低下が問題となっており, 生産者から心 白発現率が高く品質の良い酒米品種が求められていた。

そこで, 心白発現率が高く栽培しやすい新たな酒米 品種として，「ちほのまい」を育成したのでその概要を 報告する。なお，本品種は農林水産省の農林水産業 · 食品産業科学技術研究推進事業を活用して育成した。

\section{品種育成の経過}

酒米に限らず水稲の品種を育成する場合, 初めに異 なる親同士を交配し，その後代に出てくる様々な形質 を持つ子孫の中から目的に沿ったものを選抜する手法 が用いられることが多い。

「ちほのまい」も同様の手法を用い, 2004 年に短㷏 で心白発現率が高く良質の酒米「西海酒 255 号（後の 「吟のさと」）を母方に，短稈で多収の「はなかぐら」 を父方に人工交配した組合せから育成された。

交配後 2006 年に 1 株 1 本植した個体から良好なも のを選ぶ個体選抜を行った。2007 年には個体選抜で 得られた種子から系統を育成し, 形質の揃いが良い系 統について玄米品質を調査し心白発現率の高い 9 系統 を選抜した。

これらの9系統にそれぞれ「高猄 993」〜「向系 1001」の系統番号を付け 2008 年から栽培試験や特性 検定試験（病害虫抵抗性等の試験）を開始した。この うち「向系 1000」から形質の異なる系統が見出され たことから従来の形質の系統には「向系 1000-1」の番

The Charcteristics of 'Thihonomai' Which is New Brewers Rice Cultivar Suitable for Warm Place Cultivation. Satoshi MatsuURa (Miyazaki Agricultural Research Institute) 
号を，形質の異なる系統には「向系 1000-2」の番号を それぞれ付け直して試験に供試した。2009 年に収量・ 品質等の形質が優れていた「向系 1000-1」を選抜し 「南海酒 175 号」の地方系統番号を付与した。

2010 年からは「南海酒 175 号」の名称で宮崎県総 合農業試験場での奨励品種決定調査（各都道府県にお いてに普及すべき優良な品種を選定する試験）に供試 し, 2011 年からは県内 2 ヶ所での現地調査も併せて 行い適応性を検討してきた。また農林水産業・食品産 業科学技術研究推進事業を活用し現地大規模実証と延 岡市の蔵元での醉造試験を実施してきた。その結果, 収量・品質共に優れ醸造適性も高いと認められたため, 2014 年 6 月に品種登録申請を行い, 同年 12 月には宮 崎県の認定品種に採用された。

「ちほのまい」は天孫降臨の地で本県の酒米主産地 である高千穂にちなみ，思わず舞ってしまうほどおい しい酒ができることを表現して命名された。

\section{品種の紹介（特性・特徵）}

「ちほのまい」は育成地である宮崎県において下記 の特徴を有する。

第 1 表「ちほのまい」の特性概要

\begin{tabular}{|c|c|c|c|}
\hline 品種名 & ちほのまい & はなかぐら & 山田錦 \\
\hline 早晚生 & 中生の中 & 中生の晚 & 中生の中 \\
\hline 草型 & 穂重型 & 穂重型 & 穂重型 \\
\hline 出穂期（月．日） & 8.28 & 8.30 & 8.27 \\
\hline 成熟期（月．日） & 10.9 & 10.12 & 10.8 \\
\hline 稈長（cm） & 89 & 88 & 107 \\
\hline 穂長（cm） & 21.1 & 20.5 & 21.4 \\
\hline 穂数 $\left(\right.$ 本 $\left./ \mathrm{m}^{2}\right)$ & 314 & 334 & 374 \\
\hline 耐倒伏性 & 中 & 中 & 弱 \\
\hline 穂発芽性 & 中 & 中 & やや易 \\
\hline 脱粒性 & 中 & 易 & 中 \\
\hline 葉いもち & やや弱 & 弱 & やや弱 \\
\hline 耐 穂いもち & 中 & やや弱 & やや弱 \\
\hline 病 白葉枯病 & やや弱 & やや弱 & やや弱 \\
\hline 珐 縞葉枯病 & 罹病性 & 罹病性 & 罹病性 \\
\hline 玄米重（kg/a） & 59.4 & 58.5 & 50.7 \\
\hline 同上標準比率（\%) & 102 & 100 & 87 \\
\hline 立米千粒重（g） & 26.8 & 26.4 & 26.2 \\
\hline 玄米品質 1) & 4.9 & 5.8 & 4.8 \\
\hline 検査等級 ${ }^{2)}$ & 6.4 & 8.0 & 8.2 \\
\hline 心白発現率（\%) & 66.8 & 26.3 & 49.6 \\
\hline 心白率（\%） & 82.3 & 40.3 & 64.3 \\
\hline
\end{tabular}

※ $2008 \sim 2013$ 年の平均値, 心白率は 2012 年のみ調査

1）：1（上上）～9（下下）の 9 段階評価

2)：1 (特等) 〜 12（規格外）で示した

心白率 $=(5 \times$ 心白大 $+4 \times$ 心白中 $+2 \times$ 心白小 $)$ $/ 5 \times$ 調查粒数 で評価

\section{1）生態的特徵}

「ちほのまい」は「はなかぐら」に比べて出穂が 2 日，成熟が 3 日早く，「山田錦」より出穂，成熟とも 1 日遅い, 育成地では“中生の中”に当たる品種であ る(第 1 表)。

秙長は「山田錦」より $18 \mathrm{~cm}$ 短く、「はなかぐら」 並みである。程は「山田錦」よりやや細い“中”で稈 質は“やや柔”だが，耐倒伏性は「はなかぐら」並み の“中”で「山田錦」より強い（第 1 写真, 第 1 表)。

穂長は「はなかぐら」より長く「山田錦」並かやや 短い。穂数は「はなかぐら」,「山田錦」より少なく草 型は“穂重型”である (第 1 表)。

籾は琶（籾の先端に発生する針状の突起物）が無く, 2 次枝梗が多く着粒数が多いため, 着粒密度は「はな かぐら」や「山田錦」より密な“中”である(第 2 表)。

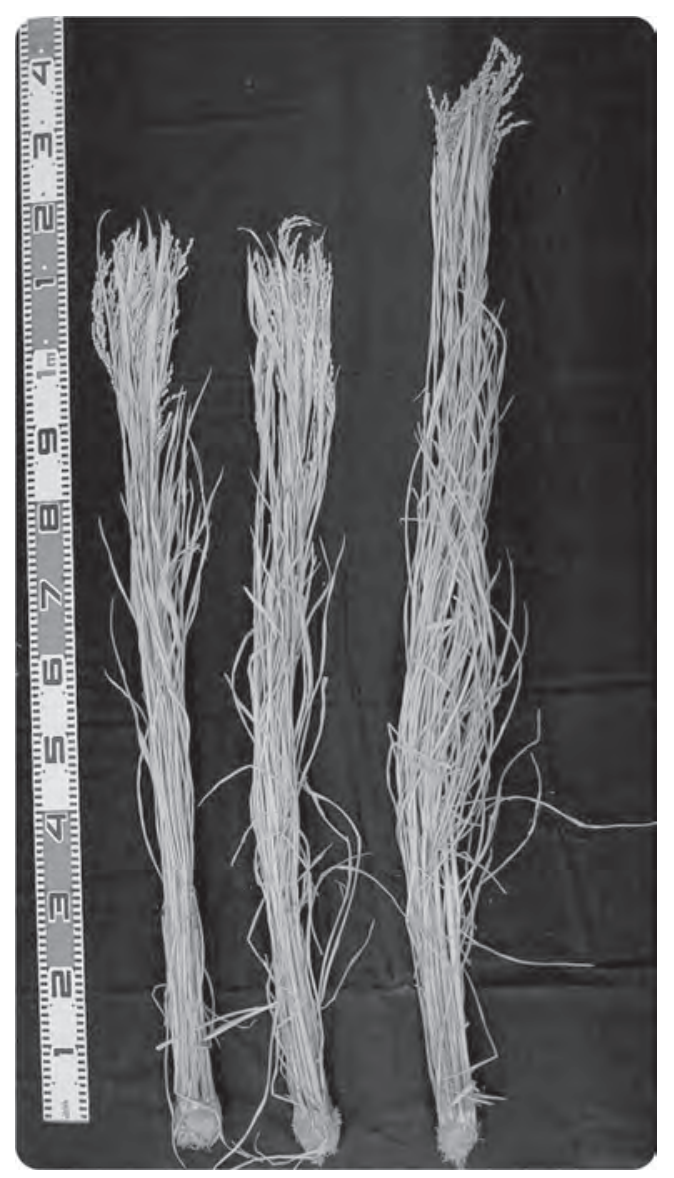

第 1 写真 株の草姿

左から「ちほのまい」「はなかぐら」「山田錦」 


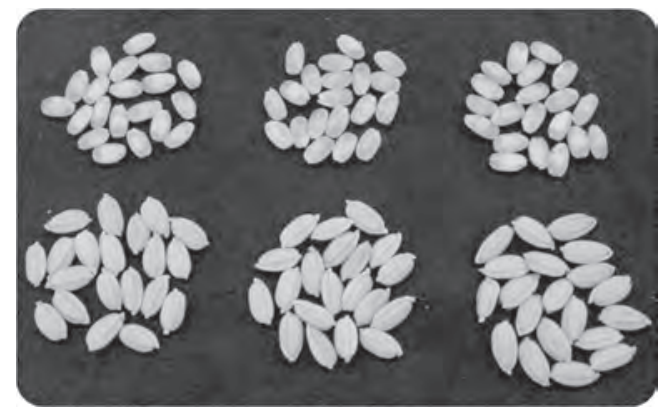

第 2 写真 籾扮よび玄米

左から「ちほのまい」「はなかぐら」「山田錦」

第 2 表 着粒密度および芒の形態

\begin{tabular}{|c|c|c|c|c|c|c|}
\hline \multirow{2}{*}{ 品種名 } & \multirow{2}{*}{$\begin{array}{l}1 \text { 穂 } \\
\text { 籾数 }\end{array}$} & \multicolumn{2}{|c|}{ 粒着密度 } & \multicolumn{2}{|c|}{ 枝梗数（本） } & \multirow{2}{*}{ 芒 } \\
\hline & & (粒 / $\mathrm{cm})$ & 疎密 & 1 次 & 2 次 & \\
\hline ちほのまい & 117.5 & 5.67 & 中 & 9.5 & 22.3 & 無 \\
\hline はなかぐら & 99.5 & 4.81 & や疎 & 8.8 & 17.3 & 稀短 \\
\hline 山田錦 & 94.2 & 4.39 & や疎 & 8.8 & 16.1 & 無 \\
\hline
\end{tabular}

※ 2012 年調査

脱粒性は“中”で,「はなかぐら」より強く収穫ロ スが少ない。穂発芽性は“中”で「山田錦」よりも改 善されており, 穂発芽による品質低下が少なくなるこ とも期待され，既存品種より栽培しやすい（第 1 表）。

稲の最大の病害である「いもち病」に対する抵抗性 は葉いもちが“やや弱”, 穂いもちは“中”であり, 細菌病の白葉枯病には “やや弱”, ウイルス病の縞葉 枯病には罹病性である (第 1 表)。

\section{2）収量・品質}

玄米収量は多収の「はなかぐら」並みかやや多く 「山田錦」より $17 \%$ 程度多い。これは穂数が少ないも のの， 1 穂当たりの着粒数が多いことが影響している と考えられる。千粒重は「山田錦」よりも重く,「は なかぐら」よりもやや重い(第1表)。

玄米の長さは「はなかぐら」と「山田錦」の中間程 度であるが, 幅は両品種よりも広い。また, 玄米の粒 愿分布は両品種よりも $2.1 \mathrm{~mm}$ 以上の粒の割合が高く これらが両品種よりも千粒重が重くなる要因と考えら れる (第 3 表)。

玄米品質は心白発現率が「はなかぐら」や「山田 錦」よりも高く，検查等級も両品種より良好で優れる。 心白粒の数に加え大きさを加味して評価した心白率も 両品種より高く, 心白の発現が多く, 心白自体も大き いものが多い。（第 1 表）
第 3 表 玄米の粒形および粒厚分布

\begin{tabular}{|c|c|c|c|c|}
\hline \multirow[b]{2}{*}{ 品種名 } & \multirow[b]{2}{*}{$\begin{array}{l}\text { 玄米長 } \\
(\mathrm{mm})\end{array}$} & \multirow{2}{*}{$\begin{array}{l}\text { 玄米幅 } \\
(\mathrm{mm})\end{array}$} & \multicolumn{2}{|c|}{ 重量比率（\%） } \\
\hline & & & $\begin{array}{c}2.1 \mathrm{~mm} \\
\text { 以上 }\end{array}$ & $\begin{array}{c}1.8 \sim \\
2.0 \mathrm{~mm}\end{array}$ \\
\hline ちほのまい & 5.56 & 3.27 & 59.3 & 40.4 \\
\hline はなかぐら & 5.46 & 3.17 & 52.6 & 47.3 \\
\hline 山田錦 & 5.61 & 3.18 & 18.7 & 78.9 \\
\hline
\end{tabular}

$※ 2012$ 年調查

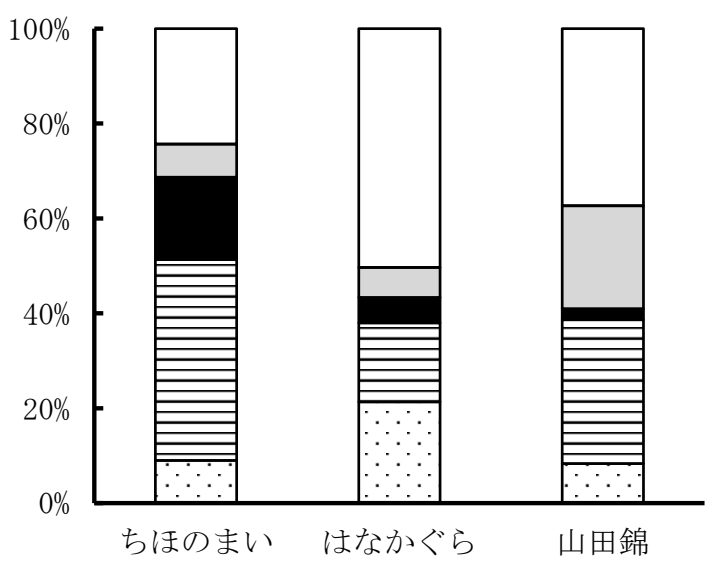

口乞の他 口腹白状 眼状 線状 口点状

第 1 図 各品種の形状別心白発生率

※ 2012 年調査

一方で望ましいとされる心白率は 50 〜 60\% 程度で あり，単年度の結果であるが「ちほのまい」の心白率 は 80\%を超えていることから心白自体が大きすぎる という骽念もある(第 1 表)。

また，心白の形状は高度精白に適するとされる点状 や線状も多いが, 好ましくないとされる眼状·腹白状 の発生もやや多い。特に眼状心白が他の 2 品種と比較 すると非常に多い。眼状心白は点状や線上心白に比べ 米粒の白濁部が多くなり米の硬度が低下することが懸 念される(第 1 図)。

\section{大規模実証と䁔造試験}

2011 年から農林水産業 ·食品産業科学技術研究推 進事業を活用し, 主要産地での大規模実証と醸造試験 並びに商品化を検討してきた。

大規模実証では酒米の主要産地での適応性の検討と ともに, 品種化後の早期普及と高品質安定多収を実現 するための地域に適した肥培管理の検討を実施した。 
醉造試験は初年目に「はなかぐら」と比較し, 醉造 特性の把握を行ったが, 醸造試験を実施していただい た蔵元からは「はなかぐら」に比べ搗精時（この蔵元 では自社搗精を行っている）や洗米・浸漬時の砕米が 多いとの指摘があった。特に醉造試験当初は $60 \%$ 精 米で試験を行っており，製毒匊が困難な場面もあった。

そこで, 収穫後の乾燥方法を変えて砕米の発生軽減 を図る方法や搗精負荷を変えて軽減を図る方法を模索 した。即ち通常の乾燥方法（コンバイン収穫後の籾を 乾燥機に投入後直ちに $40^{\circ} \mathrm{C}$ 弱の熱風で乾燥）と, 乾 燥機に投入後 3 時間は常温風でテンパリングし, その 後熱風乾燥を行ったものの砕米率を比較した。さらに, 搗精負荷を抑え搗精歩合を $70 \%$ にした精米と $60 \%$ 精 米を用いて醉造試験を実施した。その結果, 乾燥方法 の違いによる砕米の発生率には明確な差が見られなか ったものの $70 \%$ 精米に負荷を抑えた場合では $60 \%$ 精 米に比べ砕米発生率の低下が認められた。また, ある 程度砕米があっても浸漬時間を注意深く調整すること で大きな問題にならずに醸造が可能であることが明ら かになった。

\section{醸造酒の評価および蔵元の評価}

2011 年に試験醸造した酒の官能試験を行った結果 「はなかぐら」の醸造酒と比べ香りが強くやや甘口と の評価を得た(第 5 表)。

蔵元からは「はなかぐら」とは異なり (第 4 表) 新 酒の段階からまろやかで，コクがある酒ができると評 価された。また，これまでの醸造試験の結果を踏まえ， 砕米の発生が多くなるため高度精白には適さないこと

第 4 表 醸造酒特性比較 $(2011$ 年醸造試験)

\begin{tabular}{ccccc}
\hline \multirow{2}{*}{ 品種名 } & \multicolumn{4}{c}{ 醇造酒の特性 } \\
\cline { 2 - 5 } & 日本酒度 & 酸度 & $\begin{array}{c}\text { アミノ酸 } \\
\text { 度 }\end{array}$ & $\begin{array}{c}\text { アルコー } \\
\text { ル分 }\end{array}$ \\
\hline ちほのまい & +1.5 & 2.0 & 1.9 & 18.2 \\
はなかぐら & +5.0 & 2.2 & 2.0 & 18.6 \\
\hline
\end{tabular}

第 5 表 官能評価試験結果 (2011 年醸造試験)

\begin{tabular}{ccccc}
\hline \multirow{2}{*}{ 品種名 } & \multicolumn{4}{c}{ 官能評価 } \\
\cline { 2 - 5 } & 甘辛 & 質感 & 香り & 総合 \\
\hline ちほのまい & 3.2 & 2.8 & 2.2 & 2.1 \\
はなかぐら & 2.6 & 3.0 & 3.2 & 2.6 \\
\hline
\end{tabular}

※甘辛 (1 辛〜 5 甘 $)$, 質感（ 1 濃醇～ 5 淡麗 $)$

香り（1 強い〜 5 弱い), 総合 (1 良〜 5 不良 $)$
から「ちほのまい」は 70\% 精米で利用し特定名称酒 (純米酒) を商品化している。

\section{利用上の留意点}

「ちほのまい」の病害抵抗性は既存品種とほほ同等 で十分では無いため, 基幹防除を必ず実施する必要が ある。また, 白葉枯病や縞葉枯病は発病してしまうと 対応する農薬がないため, これらの病気の常発地での 栽培は避ける必要がある。

収穫物の調整時においては,「ちほのまい」は搗精 時等に砕米が生じやすくなる。これは, 発生する心白 が大きいことや，眼状心白の発生も多いことから「は なかぐら」等と比較し米の硬度が低い可能性が考えら れ, 調整時に米への負荷を軽減する必要があると考え られる。

そこで搗精時は負荷を小さくし搗精時間をやや長め にとるなどの対策が必要である。また，玄米の過乾燥 は胴割粒などの割米を生じやすくなり，搗精時の砕米 を助長することから, 籾の乾燥時は過乾燥にならない よう注意する必要がある。

\section{普及の現状と今後の育成方針}

「ちほのまい」は宮崎県の認定品種に採用され 2015 年より本格的な普及が開始された。今後は実需者の二 ーズに応じた生産拡大を進める計画であり，当面は 「はなかぐら」の一部代替で 3 ha の普及を目指している。

また，特定の焼酎メーカーでは「ちほのまい」を原 料の一部に使用した焼酎を試験的に生産するなど，日 本酒以外での利用も検討されている。

今後の育成方針については,「ちほのまい」を含め 既存の酒米は病害虫抵抗性が不十分であること, 生産 者の高齢化に伴い十分な病害虫防除が困難になりつつ あること, 日本酒の輸出拡大を目指し安価な酒米を供 給するためには低コスト栽培に対応できる必要がある ことから, 病害虫抵抗性を有し防除の削減と低コスト 化が図れる品種育成を目標としていきたい。

また，近年は高級酒の需要が高まっているが「ちほ のまい」は高度精白に向かず吟醉酒など高級酒を造る のが困難であるため, 高度精白が可能な高級酒向けの 品種の育成にも取り組んでいきたい。

〈宮崎県総合農業試験場〉 